石油技衔協会誌 第18登 第 4 号 (昭和 28 年 7 月)

JOURNAL OF THE JAPANESE ASSOCIATION OF PETROLEUM TECHNOLOGISTS

V OL. 18, NO. 4 (July, 1953)

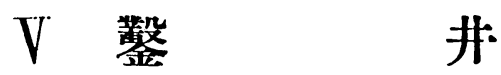

V.A. 緒言

莊島秋男*・近本信夫**

終戦後の掘錅坑投数および 掘錅米数を顧みると，右図の 如く昭和 24 年以降急激に上昇 し，大体 11 万前後に達して いる。これは戦前不油資源が 国家の相当の保護を受けて， 活潑な試掘を行つた最盛期の 掘淮米数を淩駕するものであ る。またその內容のお电なる 相異は，深茬が一般的に深く なつたこと，予定に対し中途 で種々な障害のために，坑井 を放棄することがきわめて少 なくなつたこと, 試油調查が 多歧にわたり試みられるよう になつたこと，等であり，総 じて実質的な作業量は增加し ており，かつ作策の完成度に 確夷性を增してきたものであるといえる。このことは， もちろん当時発見せられた八橋深廨開発といら惠まれた 條件があつたからであるが，技術指導者が，終戦後の混 乱期!こおける種々の困蜼を排除しつつ技術の進步に対す る判断を誤らず指導に努めたこと，全促業員も次第に混 乱期を切り拔けるとともに，一致協力してこの具現に努 めて，非常に遅札ていた籢求技術が急涑に蕉步を示し，
年度別掘進米数打よび完掘北数比較表

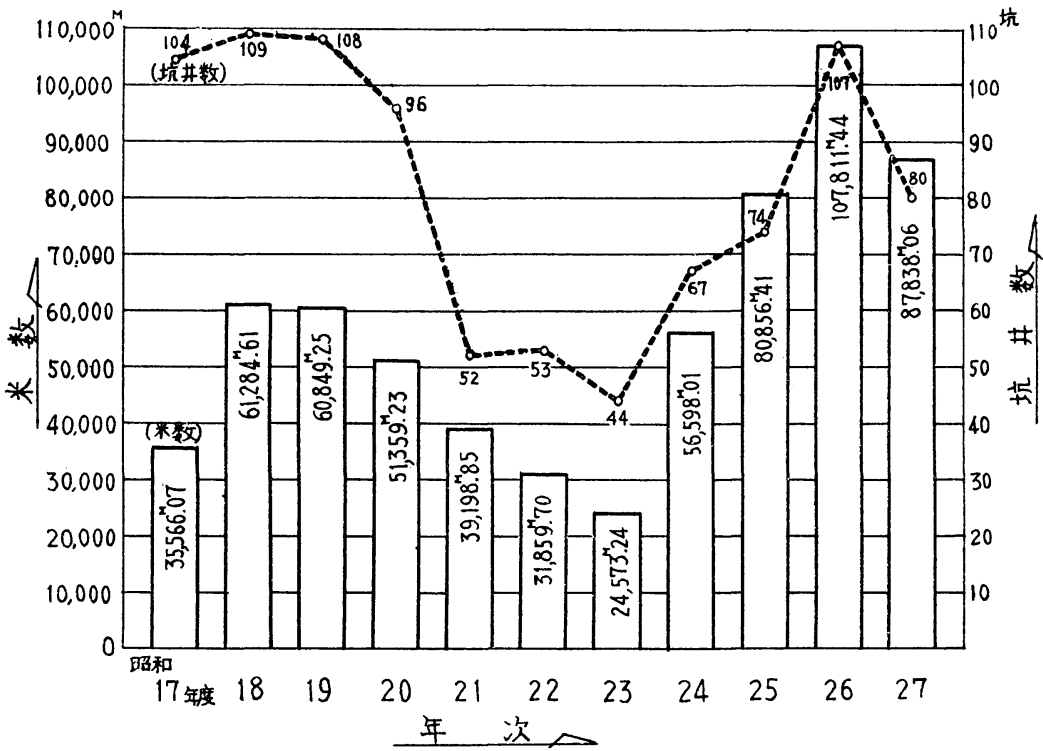

一定の軌道に乘つてきたためであるといえる。すなわち 集備你業においては充分機械力を取り入れ迅速化に成功 するとともに，掘籢のための諸袎器の裝備・掘籢方法の 研究，等が一定の段階に達したからでもる。以下，これ が內容についてて訅述する。

* 石原產業侏式会社

** 帝国石油株式会社，開発部副部長

V.B. 準 備 作 業

出比万二郎* - 中村昭一**

近年掘籢技術の向上は著しいが，特に準借作業におけ る準備日数の短縮, 工数の減少, 経費の節減等にも2る べきものがある。これは作業䋐器の規格化・ポータブル (portable) 化, 機械力の活用, 作業員の研究・努力に よるものである。以下準踊工程の推移を述べる。

\section{V.B.1 探掘井について}

主力となる八橋探・探掘井についてまず述べると，幹 線道路より坑扑までの道路は板敷道路を使用し，坑井作
業が終れい゙板材を取崩し他へ軒用するいわゆる田面道路 を使用して，道路櫣築を迅速かつ低廉化した。

敷地の配置を規格化して総面積を縮少，約 425 坡々定 め，かつ機械器具をニニット (unit) 化し，その接続関 係をむ規格化した。(第1四参照)

櫓建作業迅速化のため, ジンポー几法 (gin-pole method）を用い， $34 \mathrm{~m}$ 櫓櫓建日数を 3 日に短縮した。 